\title{
Palladium(II) Complexes with Thiosemicarbazones. Syntheses, Characterization and Cytotoxicity against Breast Cancer Cells and Anti-Mycobacterium tuberculosis Activity
}

\author{
Pedro I. da S. Maia, ${ }^{a}$ Angélica Graminha, ${ }^{b}$ Fernando R. Pavan, ${ }^{c}$ Clarice Q. F. Leite, ${ }^{c}$ \\ Alzir A. Batista, ${ }^{b}$ Davi F. Back, ${ }^{d}$ Ernesto S. Lang, ${ }^{d}$ Javier Ellena, ${ }^{e}$ Sebastião de S. Lemos, ${ }^{f}$ \\ Heloisa S. Salistre-de-Araujo ${ }^{g}$ and Victor M. Deflon*,a
}

${ }^{a}$ Instituto de Química de São Carlos, Universidade de São Paulo, 13566-590 São Carlos-SP, Brazil

${ }^{b}$ Departamento de Química, Universidade Federal de São Carlos, 13565-905 São Carlos-SP, Brazil

${ }^{c}$ Faculdade de Ciências Farmacêuticas, Universidade Estadual Paulista, 14801-902 Araraquara-SP, Brazil

${ }^{d}$ Departamento de Química, Universidade Federal de Santa Maria, 97105-900 Santa Maria-RS, Brazil

${ }^{e}$ nstituto de Física de São Carlos, Universidade de São Paulo, 13560-970 São Carlos-SP, Brazil

fInstituto de Química, Universidade de Brasília, 70919-970 Brasília-DF, Brazil

${ }^{8}$ Departamento de Ciências Fisiológicas, Universidade Federal de São Carlos, 13565-905 São Carlos-SP, Brazil

Três complexos de $\mathrm{Pd}^{\mathrm{II}}$ com tiossemicarbazonas N(4)-substituídas foram preparados: [Pd(aptsc) $\left.\left(\mathrm{PPh}_{3}\right)\right]\left(\mathrm{NO}_{3}\right) \cdot \mathrm{H}_{2} \mathrm{O}, \mathbf{1},\left[\mathrm{Pd}(\right.$ apmtsc $\left.)\left(\mathrm{PPh}_{3}\right)\right]\left(\mathrm{NO}_{3}\right), 2$, e $\left[\mathrm{Pd}(\right.$ apptsc $\left.)\left(\mathrm{PPh}_{3}\right)\right]\left(\mathrm{NO}_{3}\right) \cdot \mathrm{H}_{2} \mathrm{O}, 3$, sendo $\mathrm{PPh}_{3}=$ trifenilfosfina; Haptsc $=2$-acetilpyridina-tiossemicarbazona; Hapmtsc $=2$-acetilpiridina$N(4)$-metil-tiossemicarbazona e Happtsc $=2$-acetilpiridina- $N(4)$-fenil-tiossemicarbazona. Os complexos foram caracterizados por análise elementar, IR, UV-Vis, ${ }^{1} \mathrm{He} \mathrm{e}^{31} \mathrm{P}\left\{{ }^{1} \mathrm{H}\right\}$ NMR e tiveram suas estruturas cristalinas determinadas por difratometria de raios $\mathrm{X}$ em monocristal. Os ligantes tiossemicarbazonatos monoaniônicos atuam de modo tridentado, ligando-se ao metal pelos átomos de nitrogênio piridínico, nitrogênio azometínico e enxofre. A atividade citotóxica frente à linhagem de células tumorais MDA-MB231 (tumor de mama) e a atividade anti-Mycobacterium tuberculosis $\mathrm{H}_{37} \mathrm{Rv}$ ATCC 27294 dos compostos foram investigadas. Os complexos de Pd ${ }^{\text {II }}$ mostraram-se altamente ativos contra as células tumorais, com valores de $\mathrm{IC}_{50}$ em torno de $5 \mu \mathrm{mol} \mathrm{L} \mathrm{L}^{-1}$, enquanto o agente antitumoral em uso clínico cisplatina mostrou-se inativo. Os compostos apresentaram atividade anti-M. tuberculosis significante, com valores de CIM comparáveis ou melhores que aqueles referentes a alguns fármacos usados clinicamente contra tuberculose.

Three Pd ${ }^{\text {II }}$ complexes were prepared from $N(4)$-substituted thiosemicarbazones: [Pd(aptsc) $\left.\left(\mathrm{PPh}_{3}\right)\right]\left(\mathrm{NO}_{3}\right) \cdot \mathrm{H}_{2} \mathrm{O}, \mathbf{1},\left[\mathrm{Pd}(\right.$ apmtsc $\left.)\left(\mathrm{PPh}_{3}\right)\right]\left(\mathrm{NO}_{3}\right), 2$, and $\left[\mathrm{Pd}(\right.$ apptsc $\left.)\left(\mathrm{PPh}_{3}\right)\right]\left(\mathrm{NO}_{3}\right) \cdot \mathrm{H}_{2} \mathrm{O}, \mathbf{3}$, where $\mathrm{PPh}_{3}=$ triphenylphosphine; Haptsc = 2-acetylpyridine-thiosemicarbazone; Hapmtsc = 2-acetylpyridine- $N(4)$-methyl-thiosemicarbazone and Happtsc $=2$-acetylpyridine- $N(4)$-phenylthiosemicarbazone. All complexes were characterized by elemental analysis, IR, UV-Vis, ${ }^{1} \mathrm{H}$ and ${ }^{31} \mathrm{P}\left\{{ }^{1} \mathrm{H}\right\}$ NMR spectroscopies, and had their crystalline structures determined by X-ray diffractometry from single crystals. The monoanionic thiosemicarbazonate ligands act in a tridentate mode, binding to the metal through the pyridine nitrogen, the azomethine nitrogen and the sulfur atoms. The cytotoxic activity against the breast cancer cell line MDA-MB231 and the anti-Mycobacterium tuberculosis $\mathrm{H}_{37} \mathrm{Rv}$ ATCC 27294 activity were evaluated for the compounds. All $\mathrm{Pd}^{\mathrm{II}}$ complexes were highly active against the studied cell line, presenting similar values of $\mathrm{IC}_{50}$, around $5 \mu \mathrm{mol} \mathrm{L} \mathrm{L}^{-1}$, while the clinically applied antitumor agent cisplatin was inactive. The compounds show remarkable anti-M. tuberculosis activities, presenting MIC values comparable or better than some commercial anti-M tuberculosis drugs.

Keywords: palladium(II) complexes, thiosemicarbazones, cytotoxicity, breast tumor cells, Mycobacterium tuberculosis

\footnotetext{
*e-mail: deflon@iqsc.usp.br
} 


\section{Introduction}

There has been much interest in the development of effective agents against tumor cell lines resistant to cisplatin, as well as of more efficient anti-tuberculosis drugs. Cisplatin has received much attention recently with regard to metal-based chemotherapy due to its disadvantages, such as the occurrence of primary or acquired resistance..$^{1-3}$ On the other hand, the rising incidence of tuberculosis, especially when associated with AIDS cases, and the occurrence of multidrug-resistant tuberculosis demand the development of new anti-tubercular drugs. ${ }^{4,5}$ To attenuate these disadvantages, much effort has been directed toward the development of new antitumor metal coordination compounds with the ability to overcome cisplatin ${ }^{6}$ resistance, as well as of new drugs addressing the current problems with tuberculosis therapy.

Until some time ago, the great majority of antitumor metal complexes synthesized and characterized were structural analogs of cisplatin. ${ }^{7}$ However, there has been a decrease in the number of new compounds of this type because they have not shown improved clinical efficacy, most likely because all cis-[ $\left.\mathrm{PtX}_{2}(\text { amine })_{2}\right]$ compounds show similar DNA-binding modes, and therefore similar biological effects. ${ }^{2,8}$

Thiosemicarbazone derivatives have received considerable attention due to their pharmacological properties, such as antiviral, antibacterial and antitumor activities. ${ }^{9-13}$ The compound triapine, which is currently being tested in a Phase I clinical trial against a variety of tumor cell models, ${ }^{1}$ and thiacetazone, which has been widely used in the treatment of tuberculosis, ${ }^{4}$ are good examples of the biologic activity of this class of compounds.

Structure-activity relationships not only evidence that the complexation with a metal enhances the antimicrobial activity of the ligands against some tested microorganisms, but also indicate that the metal plays a relevant role. ${ }^{14-16}$ It has already been shown, for example, that Pd-thiosemicarbazone complexes possess interesting antiproliferative effects on human breast cancer, including tumor cell lines resistant to cisplatin ${ }^{17-20}$ and have also presented good antimycobacterial effects..$^{21}$ The presence of phosphine ligands in potential anti-cancer complexes is supposed to provide better cytotoxicity by enhancing lipophilicity - and consequently permeability through the cell membrane. ${ }^{22}$ Thus, our group focused on investigating both antitumor and antimycobacterial activities of some $\mathrm{Pd}^{\mathrm{II}}$ complexes containing both thiosemicarbazone and phosphine ligands.

This work reports the preparation, structural characterization, cytotoxicity against breast cancer cells and anti-M. tuberculosis activity of three thiosemicarbazone derivatives and their $\mathrm{Pd}^{\mathrm{II}}$ complexes containing different $N(4)$-substituted groups: 2-acetylpyridinethiosemicarbazone (Haptsc), 2-acetylpyridine- $N$ (4)-methylthiosemicarbazone (Hapmtsc) and 2-acetylpyridine- $N(4)$ phenyl-thiosemicarbazone (Happtsc).

\section{Experimental}

\section{Materials and measurements}

$\left[\mathrm{PdCl}_{2}\left(\mathrm{PPh}_{3}\right)_{2}\right], \mathrm{AgNO}_{3}$ and other analytical grade reagents and solvents were obtained commercially (Aldrich or Strem Chemicals) and used without further purification. The complexing agents Haptsc, Hapmtsc and Happtsc were prepared by standard methods described in the literature. ${ }^{23}$ FTIR spectra were recorded using $\mathrm{KBr}$ pellets on a BOMEM FTIR model BM 100 spectrophotometer in the 4000-400 $\mathrm{cm}^{-1}$ region. The electronic spectra were recorded with a JASCO V-630 spectrophotometer. NMR spectra were acquired using a Varian MERCURY Plus spectrometer operating at 300.07 and $121.47 \mathrm{MHz}$ for ${ }^{1} \mathrm{H}$ and ${ }^{31} \mathrm{P}$, respectively. The ${ }^{1} \mathrm{H}$ spectra were internally referenced to tms (tetramethylsilane). The ${ }^{31} \mathrm{P}\left\{{ }^{1} \mathrm{H}\right\}$ spectra were externally referenced to $\mathrm{H}_{3} \mathrm{PO}_{4}(85 \%, \delta=0)$ with positive chemical shifts downfield the standard. Elemental analyses (CHNS) were carried out using a FISONS EA1108 analyzer. A Bruker CCD X8 APEX II diffractometer was used for the X-ray structure analyses of $\mathbf{1}$ and $\mathbf{2}$, while the data collection for $\mathbf{3}$ was performed on a NONIUS KAPPA CCD diffractometer. Both equipments were operated using graphite monochromator and Mo-K $\alpha$ radiation $(\lambda=71.073 \mathrm{pm})$.

\section{Crystal structure determinations}

Orange crystals of the complexes $\mathbf{1}, \mathbf{2}$ and $\mathbf{3}$ were obtained by slow evaporation of their methanolic solutions at room temperature. The structures were solved using SHELXS $97^{24}$ by direct methods. All non-hydrogen atoms were refined with anisotropic displacement parameters using SHELXL97. ${ }^{25}$ The hydrogen atom positions were found in the Fourier map or calculated at idealized positions. More detailed information on the structure determinations is given in Table 1.

\section{Cell culture and cytotoxicity determination}

In vitro cytotoxicity assays on cultured human tumor cell line still represent the standard method for the initial screening of antitumor agents. Thus, as a first step to assess 
Table 1. X-ray structure data collection and refinement parameters for complexes 1-3

\begin{tabular}{|c|c|c|c|}
\hline & 1 & 2 & 3 \\
\hline Empirical formula & $\mathrm{C}_{26} \mathrm{H}_{26} \mathrm{~N}_{5} \mathrm{O}_{4} \mathrm{PPdS}$ & $\mathrm{C}_{27} \mathrm{H}_{26} \mathrm{~N}_{5} \mathrm{O}_{3} \mathrm{PPdS}$ & $\mathrm{C}_{32} \mathrm{H}_{30} \mathrm{~N}_{5} \mathrm{O}_{4} \mathrm{PPdS}$ \\
\hline Formula weight, $\mathrm{M}$ & 641.95 & 637.96 & 718.04 \\
\hline Temperature, T (K) & $293(2)$ & $293(2)$ & 293(2) \\
\hline Crystal system & Triclinic & Triclinic & Orthorhombic \\
\hline Space group & $P \overline{1}$ & $P \overline{1}$ & Pbca \\
\hline \multicolumn{4}{|l|}{ Unit cell dimensions } \\
\hline$a(\mathrm{pm})$ & $947.95(11)$ & $951.81(3)$ & $1027.160(10)$ \\
\hline$b(\mathrm{pm})$ & $950.32(10)$ & $968.73(3)$ & 1970.01(3) \\
\hline$c(\mathrm{pm})$ & $1602.98(18)$ & $1584.61(5)$ & $3095.18(5)$ \\
\hline$\alpha\left(^{\circ}\right)$ & $75.891(6)$ & $74.049(2)$ & 90 \\
\hline$\beta\left(^{\circ}\right)$ & $74.750(6)$ & $77.072(2)$ & 90 \\
\hline$\gamma\left({ }^{\circ}\right)$ & $84.187(7)$ & $84.664(2)$ & 90 \\
\hline Volume, V (nm²) & $1.3501(3)$ & $1.36845(7)$ & $6.26314(15)$ \\
\hline$Z$ & 2 & 2 & 8 \\
\hline Density calculated $\left(\mathrm{Mg} / \mathrm{m}^{3}\right)$ & 1.582 & 1.548 & 1.523 \\
\hline Absorption coefficient $\left(\mathrm{mm}^{-1}\right)$ & 0.866 & 0.851 & 0.756 \\
\hline $\mathrm{F}(000)$ & 652 & 648 & 2928 \\
\hline Crystal size $\left(\mathrm{mm}^{3}\right)$ & $0.410 \times 0.170 \times 0.130$ & $0.790 \times 0.550 \times 0.260$ & $0.840 \times 0.400 \times 0.360$ \\
\hline Method / $\theta$ Range for data collection $\left(^{\circ}\right)$ & $\varphi$ and $\omega$ scans / 2.21 to 28.15 & $\varphi$ and $\omega$ scans / 2.19 to 30.63 & $\begin{array}{l}\varphi \text { and } \omega \text { scans with } \kappa \text { offsets / } \\
2.94 \text { to } 27.49\end{array}$ \\
\hline Limiting indices $(h, k, 1)$ & $\begin{array}{l}-12 \leftarrow \mathrm{h} \leftarrow 12, \\
-12 \leftarrow \mathrm{k} \leftarrow 12, \\
-21 \leftarrow 1 \leftarrow 21\end{array}$ & $\begin{array}{l}-13 \leftarrow \mathrm{h} \leftarrow 13, \\
-13 \leftarrow \mathrm{k} \leftarrow 13, \\
-22 \leftarrow 1 \leftarrow 22\end{array}$ & $\begin{array}{l}-13 \leftarrow \mathrm{h} \leftarrow 12, \\
-25 \leftarrow \mathrm{k} \leftarrow 25, \\
-39 \leftarrow \mathrm{l} \leftarrow 39\end{array}$ \\
\hline Reflections collected & 26183 & 34380 & 56101 \\
\hline Reflections unique/ $\mathrm{R}_{\text {int }}$ & $6589[\mathrm{R}(\mathrm{int})=0.0306]$ & $8357[\mathrm{R}(\mathrm{int})=0.0682]$ & $7165[\mathrm{R}(\mathrm{int})=0.0713]$ \\
\hline Completeness to theta & $28.15(99.6 \%)$ & $30.63(98.9 \%)$ & $27.49(99.7 \%)$ \\
\hline Data/restraints/parameters & $6589 / 0 / 349$ & $8357 / 0 / 343$ & $7165 / 0 / 403$ \\
\hline Absorption correction & Gaussian & Gaussian & Multi-scan \\
\hline Min. and max. transmission & 1.000000 and 0.835097 & 0.976719 and 0.667818 & 0.889 and 0.946 \\
\hline Refinement method & Full-matrix least-squares on $\mathrm{F}^{2}$ & Full-matrix least-squares on $\mathrm{F}^{2}$ & Full-matrix least-squares on $\mathrm{F}^{2}$ \\
\hline Hydrogen treatment & mixed & mixed & riding model \\
\hline Final $R$ indices $[I>2 \sigma(I)]$ & $\begin{array}{l}\mathrm{R}_{1}=0.0354 \\
\mathrm{wR}_{2}=0.1010\end{array}$ & $\begin{array}{l}\mathrm{R}_{1}=0.0497 \\
\mathrm{wR}_{2}=0.1345\end{array}$ & $\begin{array}{l}\mathrm{R}_{1}=0.0355 \\
\mathrm{wR}_{2}=0.085\end{array}$ \\
\hline $\mathrm{R}$ indices (all data) & $\begin{array}{l}\mathrm{R}_{1}=0.0471 \\
\mathrm{wR}_{2}=0.1196\end{array}$ & $\begin{array}{l}\mathrm{R}_{1}=0.0787 \\
\mathrm{wR}_{2}=0.1590\end{array}$ & $\begin{array}{l}\mathrm{R}_{1}=0.0599 \\
\mathrm{wR}_{2}=0.0964\end{array}$ \\
\hline Goodness-of-fit, S & 1.123 & 1.049 & 1.045 \\
\hline Largest diff. peak and hole (e $\left.\AA^{-3}\right)$ & 1.114 and -0.763 & 1.671 and -1.537 & 0.424 and -0.636 \\
\hline
\end{tabular}

their pharmacological properties, the new palladium(II) complexes were assayed against the human breast tumor MDA-MB-231 cell line (ATCC No. HTB-26). The cells were routinely maintained at $37{ }^{\circ} \mathrm{C}$ in a humidified $5 \%$ $\mathrm{CO}_{2}$ atmosphere with Dulbecco's Modified Eagle's medium (DMEM) supplemented with 10\% fetal bovine serum (FBS). After reaching confluence, the cells were detached by tripsinization and counted. For the cytotoxicity assay, $4 \times 10^{4}$ cells well ${ }^{-1}$ were seeded in $200 \mu \mathrm{L}$ of complete medium in 96-well plates (Corning Costar).
The plates were incubated at $37{ }^{\circ} \mathrm{C}$ in $5 \% \mathrm{CO}_{2}$ for $24 \mathrm{~h}$ to allow cell adhesion prior to drug testing. The complex was dissolved in sterile dimethylsulfoxide (dmso, stock solution with maximum concentration of $\left.20 \mathrm{mmol} \mathrm{L}^{-1}\right)$ and diluted to $10,2,0.2$ and $0.02 \mathrm{mmol} \mathrm{L}^{-1}$. Two microliters of each complex sample were added to $200 \mu \mathrm{L}$ medium (without FBS), so that the final concentration of dmso in each well was approximately $1 \%$ and the complex was diluted approximately 100 times. The other compounds evaluated (free thiosemicarbazones and cisplatin) were 
also dissolved in sterile dmso. The cells were exposed to the complex for $48 \mathrm{~h}$. Cell respiration, as an indicator of cell viability, was determined by the mitochondrialdependent reduction of MTT (3-(4,5-dimethylthiazol-2yl)-2,5-diphenyltetrazolium bromide) to formazan. ${ }^{26} \mathrm{MTT}$ solution $\left(0.5 \mathrm{mg} \mathrm{mL}^{-1}\right)$ was added to the cell cultures and incubated for $3 \mathrm{~h}$. Thereafter, $100 \mu \mathrm{L}$ of isopropanol were added in order to dissolve the formazan crystals. The conversion of MTT to formazan by metabolically viable cells was monitored by an automated microplate reader at $570 \mathrm{~nm}$. The percentage of cell viability was calculated by dividing the average absorbance of the cells treated with the compounds by that of the control; $\%$ of the cell viability versus drug concentration (logarithmic scale) was plotted to determine the $\mathrm{IC}_{50}$ (drug concentration at which $50 \%$ of the cells are viable relative to the control), with its estimated error derived from the average of 3 trials.

\section{Anti-Mycobacterium tuberculosis activity assay}

The anti-M. tuberculosis activity was determined applying the Microplate Alamar Blue Assay (MABA) as the analytical method. ${ }^{27}$ Stock solutions of the tested compounds were prepared in $\mathrm{dmso}^{27}$ and were diluted in Middlebrook 7H9 (Difco) broth supplemented with oleic acid, albumin, dextrose and catalase (OADC enrichment BBL/Becton-Dikinson, Sparks, MD, USA) to obtain final sample concentration ranges from 1.00 to $100 \mu \mathrm{g} \mathrm{mL} \mathrm{mL}^{-1}$. Isoniazid was dissolved in distilled water according to the manufacturers' recommendations (Difco laboratories, Detroit, MI, USA) and used as a positive control drug. $M$. tuberculosis $\mathrm{H}_{37} \mathrm{Rv}$ ATCC 27294 was grown for 7 to 10 days in Middlebrook 7H9 supplemented with OADC and added of $0.05 \%$ Tween 80 to avoid clumps. Suspensions were prepared and their turbidities matched to the optical density of the McFarland No. 1 standard. After further dilution of 1:25 in Middlebrook 7H9 supplemented with OADC, the inoculum was added to each well of the 96-well microtiter plates (Falcon 3072; Becton Dickinson, Lincoln Park, NJ) together with the compounds. Samples were set up in triplicate. Cultures were incubated for 7 days at $37^{\circ} \mathrm{C}$ and then Alamar Blue was added for reading. The minimum inhibitory concentration (MIC) was defined as the lowest concentration of the tested compound necessary to inhibit $90 \%$ growth of M. tuberculosis. ${ }^{27}$ MIC values were determined by fluorescence on a SPECTRAfluor Plus microfluorimeter (Tecan), with excitation at $530 \mathrm{~nm}$ and emission at $590 \mathrm{~nm} \cdot{ }^{28}$ As a control, the MIC value of isoniazid was determined for each microplate. The acceptable MIC of isoniazid ranged from 0.015 to $0.05 \mu \mathrm{g} \mathrm{mL}^{-1}{ }^{28}$
Preparation of $\left[\mathrm{Pd}(\right.$ aptsc $\left.)\left(\mathrm{PPh}_{3}\right)\right]\left(\mathrm{NO}_{3}\right) \cdot \mathrm{H}_{2} \mathrm{O}(\mathbf{1})$, $\left[\mathrm{Pd}(\mathrm{apmtsc})\left(\mathrm{PPh}_{3}\right)\right]\left(\mathrm{NO}_{3}\right)(2)$ and $\left[\mathrm{Pd}(\mathrm{apptsc})\left(\mathrm{PPh}_{3}\right)\right]$ $\left(\mathrm{NO}_{3}\right) \cdot \mathrm{H}_{2} \mathrm{O}(3)$

Three different solutions of $\mathrm{AgNO}_{3}(0.068 \mathrm{~g}, 0.4 \mathrm{mmol})$ in $\mathrm{MeOH}(10 \mathrm{~mL})$ were prepared and mixed with suspensions of $\left[\mathrm{PdCl}_{2}\left(\mathrm{PPh}_{3}\right)_{2}\right](0.128 \mathrm{~g}, 0.2 \mathrm{mmol})$ in $\mathrm{MeOH}(20 \mathrm{~mL})$. The resulting mixtures were kept under reflux until the formation of red solutions (approximately $30 \mathrm{~min})$. The precipitates formed $(\mathrm{AgCl})$ were filtered off and each filtrate received the addition of $0.2 \mathrm{mmol}$ of one of the free thiosemicarbazones $(0.039 \mathrm{~g}, 0.042 \mathrm{~g}$ and $0.054 \mathrm{~g}$ for Haptsc, Hapmtsc and Happtsc, respectively) dissolved in $\mathrm{MeOH}(15 \mathrm{~mL})$. The resulting mixtures were kept under reflux for $2 \mathrm{~h}$, forming yellow solutions, which gave orange crystals of complexes $\mathbf{1}, \mathbf{2}$ and $\mathbf{3}$ after slow evaporation at room temperature. The crystals were washed with small portions of cold $\mathrm{CH}_{2} \mathrm{Cl}_{2}$ and $n$-hexane, yielding 0.039 (31.0\%), 0.039 (30.3\%) and $0.050 \mathrm{~g}(34.8 \%)$ of $\mathbf{1}, \mathbf{2}$ and 3, respectively. Elemental analysis: Complex 1 (641.98 g mol $^{-1}$ ): Found: C, 48.82; H, 4.27; N, 10.93; S, 5.35. Calc. for $\mathrm{C}_{26} \mathrm{H}_{26} \mathrm{~N}_{5} \mathrm{O}_{4} \mathrm{PPdS}$ : C, 48.64; H, 4.08; N, 10.91; S, 4.99\%. Complex $2\left(637.99 \mathrm{~g} \mathrm{~mol}^{-1}\right)$ : Found: C, 50.21; $\mathrm{H}, 4.25 ; \mathrm{N}, 10.85 ; \mathrm{S}, 4.80$. Calc. for $\mathrm{C}_{27} \mathrm{H}_{26} \mathrm{~N}_{5} \mathrm{O}_{3} \mathrm{PPdS}$ : C, 50.83; H, 4.11; N, 10.98; S, 5.03\%. Complex 3 (718.08 g mol $^{-1}$ ): Found: C, 53.44; H, 4.34; N, 10.12; S 4.30. Calc. for $\mathrm{C}_{32} \mathrm{H}_{30} \mathrm{~N}_{5} \mathrm{O}_{4} \mathrm{PPdS}$ : C, 53.53; H, 4.21; N, 9.75; S, 4.46\%. UV-Vis data, $\mathrm{CH}_{2} \mathrm{Cl}_{2}$ solution $\left[\lambda_{\text {max }} / \mathrm{nm}(\log \varepsilon)\right]$ for $1: 308$ (4.47), 369 (4.16), 447 (3.72). Complex 2: 309 (4.41), 380 (4.23), 466 (3.70). Complex 3: 316 (4.29), 420 (4.47).

\section{Results and Discussion}

\section{Spectroscopic characterization}

The main IR vibrational bands of the free thiosemicarbazones and their complexes are listed in Table 2. Upon coordination, changes in the $v(C=S)$, $v(\mathrm{C}=\mathrm{C}+\mathrm{C}=\mathrm{N})$ and $v(\mathrm{~N}-\mathrm{H})$ wavenumbers, in comparison to the values found for the thiosemicarbazones, were observed for complexes 1-3. They are consistent with the tridentate coordination of the thiosemicarbazone derivatives through the thiolate sulfur, the azomethine nitrogen and the pyridine nitrogen atoms, respectively. ${ }^{29}$ The occurrence of the $v(\mathrm{~N}-\mathrm{N})$ band at higher frequencies in the IR spectra of the complexes, compared to those observed for the ligands, confirms coordination through the azomethine nitrogen atom. ${ }^{11}$ The $v(\mathrm{C}=\mathrm{S})$ bands at $801-850 \mathrm{~cm}^{-1}$ in the spectra of free thiosemicarbazones shift to the $780-784 \mathrm{~cm}^{-1}$ range in the complexes, indicating coordination through the sulfur atom. These shifts to lower frequencies are compatible 
Table 2. Relevant IR spectral assignments $\left(\mathrm{cm}^{-1}\right)$ for the free thiosemicarbazones and complexes 1-3

\begin{tabular}{|c|c|c|c|c|c|c|}
\hline Compounds & $v(\mathrm{~N}-\mathrm{H})$ & $v(\mathrm{C}=\mathrm{C}, \mathrm{C}=\mathrm{N})$ & $v(\mathrm{NO})$ & $v(\mathrm{P}-\mathrm{C})$ & $v(\mathrm{~N}-\mathrm{N})$ & $v(\mathrm{CS})$ \\
\hline Haptsc & $3374,3261,3184$ & $\begin{array}{l}1609,1583,1563 \\
1502,1467,1430\end{array}$ & - & - & 994 & 850 \\
\hline Hapmtsc & 3289,3240 & $\begin{array}{l}1578,1539,1497 \\
1461,1433\end{array}$ & - & - & 989 & 834 \\
\hline Happtsc & 3301,3242 & $\begin{array}{l}1598,1587,1527 \\
1468,1444\end{array}$ & - & - & 978 & 801 \\
\hline 1 & 3284,3129 & $\begin{array}{l}1598,1584,1563 \\
1505,1456,1434\end{array}$ & 1384 & 1098 & 997 & 784 \\
\hline 2 & 3200 & $\begin{array}{l}1589,1567,1541 \\
1510,1461,1435\end{array}$ & 1384 & 1097 & 996 & 783 \\
\hline 3 & 3262 & $\begin{array}{l}1601,1560,1509 \\
1459,1437\end{array}$ & 1384 & 1097 & 996 & 780 \\
\hline
\end{tabular}

with deprotonation and formation of a C-S single bond. ${ }^{23}$ A very strong band found at $1384 \mathrm{~cm}^{-1}$ in the spectra of the complexes is attributed to $v\left(\mathrm{NO}_{3}^{-}\right)$.

The presence of the triphenylphosphine ligand is confirmed in the spectra of the complexes by the existence of the characteristic bands around $1097 \mathrm{~cm}^{-1}$ for $\mathrm{v}(\mathrm{P}-\mathrm{C})$, with no significant change when compared to the precursor $\left[\mathrm{PdCl}_{2}\left(\mathrm{PPh}_{3}\right)_{2}\right]$.

The data obtained from the electronic spectra of the complexes in $\mathrm{CH}_{2} \mathrm{Cl}_{2}$ solutions are given in the experimental section. Three $\mathrm{d}-\mathrm{d}$ spin allowed singlet-singlet and three spin forbidden singlet-triplet transitions are predicted for square-planar complexes of palladium(II). However, strong charge-transfer transitions may interfere and prevent the observation of some of the expected bands, especially for complexes containing sulfur donor atoms. ${ }^{11,17}$ The prominent strong bands in the $308-466 \mathrm{~nm}$ range are assigned to a combination of intraligand and ligand to metal charge transfer (LMCT) absorptions and $\mathrm{d}-\mathrm{d}$ bands, which support the idea of a square-planar environment for the metal ions.

The ${ }^{1} \mathrm{H}$ NMR data for the free thiosemicarbazones and complexes 1, 2 and $\mathbf{3}$ are given in Table 3. Figure 1 shows the numbered structures of the free thiosemicarbazones. The three new $\mathrm{Pd}^{\mathrm{II}}$ complexes show similar ${ }^{1} \mathrm{H}$-chemical shift behavior. Some hydrogen atom values of $\delta$ were not observed precisely due to overlapping with the signals of the aromatic hydrogen atoms of triphenylphosphine.
${ }^{1} \mathrm{H}$ NMR integrations and signal multiplicities are in agreement with the proposed structures.

In the ${ }^{1} \mathrm{H}$ NMR spectra of the complexes $\mathbf{1 , 2}$ and $\mathbf{3}$, a high frequency shift of $c a .0 .15 \mathrm{ppm}$ for the methyl hydrogen atoms $\left(\mathrm{C}-\mathrm{CH}_{3}\right)$, compared to the spectra of the thiosemicarbazones, evidences the coordination through the azomethine nitrogen. On the other hand, the signals referred to the hydrogen atoms of the methyl group $\left(\mathrm{N}-\mathrm{CH}_{3}\right)$, observed in the spectrum of $\mathbf{2}$, remain almost non shifted in relation to free Hapmtsc. The methyl group bonded to the $\mathrm{N}^{4}$ atom (6 in the numbering scheme) is observed in the spectrum of Hapmtsc as a doublet, which is consistent with a coupling to the hydrogen atom bonded directly to the $\mathrm{N}^{4}$ atom. In complex $\mathbf{2}$, however, this signal is observed as a sharp singlet, similarly to what is reported for a $\mathrm{Pd}^{\mathrm{II}}$ complex containing the ligands apmtsc ${ }^{-}$and $\mathrm{Cl}^{-} .{ }^{12}$ The spectrum of free Haptsc displayed three signals related to $\mathrm{N}$-bonded $\mathrm{H}$ atoms, showing non-equivalence for the hydrogens bonded to $\mathrm{N}^{4}$. In complex $\mathbf{1}$ only one $\mathrm{NH}$ signal is observed, which is consistent with the deprotonation of $\mathrm{N}^{3}$ and with the chemical equivalence of the $\mathrm{NH}_{2}$ protons.

The ${ }^{31} \mathrm{P}\left\{{ }^{1} \mathrm{H}\right\}$ NMR spectrum of the precursor $\left[\mathrm{PdCl}_{2}\left(\mathrm{PPh}_{3}\right)_{2}\right]$ in $\mathrm{CD}_{2} \mathrm{Cl}_{2}$ solution shows a singlet peak for the phosphorous donor atoms at $\delta 23.83 \mathrm{ppm}$. In the spectra of complexes $\mathbf{1}, \mathbf{2}$ and $\mathbf{3}$, this singlet peak is shifted to $28.10,28.22$ and $28.25 \mathrm{ppm}$, respectively, in conformity with the presence of only one species for each complex in the $\mathrm{CD}_{2} \mathrm{Cl}_{2}$ solution.<smiles></smiles><smiles>CC(=NNC(=S)N(C)P)c1ccccn1</smiles><smiles>[1H]c1c(P)c(P)c(NC(=S)NN=C(C)c2ccccn2)c(P)c1P</smiles>

Figure 1. Structural representation of the thiosemicarbazones with the numbering scheme employed in the NMR spectroscopy section. 
Table 3. ${ }^{1} \mathrm{H}$ NMR data (ppm) for the thiosemicarbazones and complexes 1-3 at room temperature

\begin{tabular}{|c|c|}
\hline Compound & Assignments \\
\hline Haptsc & $\begin{array}{l}{ }^{1} \mathrm{H} \mathrm{NMR}\left(\mathrm{dmso}-d_{6}\right) \delta 2.39\left(\mathrm{~s}, 3 \mathrm{H}, \mathrm{CH}_{3}\right), 7.38\left(\mathrm{ddd}, J_{2,3} 8 \mathrm{~Hz}, J_{2,1} 5 \mathrm{~Hz}, J_{2,4} 1 \mathrm{~Hz}, 1 \mathrm{H}, \mathrm{CH}\right), 7.79\left(\mathrm{ddd}, J_{3,4} J_{3,2} 8 \mathrm{~Hz}, J_{3,1} 2 \mathrm{~Hz}, 1 \mathrm{H}, \mathrm{CH}\right) \text {, } \\
8.15(\mathrm{~s}, 1 \mathrm{H}, \mathrm{NH}), 8.42(\mathrm{~s}, 1 \mathrm{H}, \mathrm{NH}), 8.44\left(\mathrm{ddd}, J_{4,3} 8 \mathrm{~Hz}, J_{4,2} 1 \mathrm{~Hz}, 1 \mathrm{H}, \mathrm{CH}\right), 8.58\left(\mathrm{ddd}, J_{1,2} 5 \mathrm{~Hz}, J_{1,3} 2 \mathrm{~Hz}, 1 \mathrm{H}, \mathrm{CH}\right), 10.33(\mathrm{~s}, 1 \mathrm{H}, \mathrm{NH}) .\end{array}$ \\
\hline Hapmtsc & $\begin{array}{l}{ }^{1} \mathrm{H} \mathrm{NMR}\left(\mathrm{dmso}-d_{6}\right) \delta 2.38\left(\mathrm{~s}, 3 \mathrm{H}, \mathrm{CH}_{3}\right), 3.06\left(\mathrm{~d}, J_{6,5} 5 \mathrm{~Hz}, 3 \mathrm{H}, \mathrm{N}-\mathrm{CH}_{3}\right), 7.39\left(\mathrm{ddd}, J_{2,3} 7 \mathrm{~Hz}, J_{2,1} 5 \mathrm{~Hz}, J_{2,4} 1 \mathrm{~Hz}, 1 \mathrm{H}, \mathrm{CH}\right), 7.82\left(\mathrm{ddd}, J_{3,4}\right. \\
\left.8 \mathrm{~Hz}, J_{3,2} 7 \mathrm{~Hz}, J_{3,1} 1 \mathrm{~Hz}, 1 \mathrm{H}, \mathrm{CH}\right), 8.42\left(\mathrm{dq}, J_{4,3} 8 \mathrm{~Hz}, J_{4,2} 1 \mathrm{~Hz}, 1 \mathrm{H}, \mathrm{CH}\right), 8.58\left(\mathrm{dq}, J_{1,2} 5 \mathrm{~Hz}, J_{1,3} 1 \mathrm{~Hz}, 1 \mathrm{H}, \mathrm{CH}\right), 8.64\left(\mathrm{~d}, J_{5,6} 5 \mathrm{~Hz}, 1 \mathrm{H},\right. \\
\mathrm{CH}), 10.35(\mathrm{~s}, 1 \mathrm{H}, \mathrm{NH}) .\end{array}$ \\
\hline Happtsc & $\begin{array}{l}{ }^{1} \mathrm{H} \mathrm{NMR}\left(\mathrm{dmso}-d_{6}\right) \delta 2.47\left(\mathrm{~s}, 3 \mathrm{H}, \mathrm{CH}_{3}\right), 7.24\left(\mathrm{ddd}, J_{7,6} 7 \mathrm{~Hz}, J_{7,5} 1 \mathrm{~Hz}, 1 \mathrm{H}, \mathrm{CH}\right), 7.34-7.44(\mathrm{~m}, 3 \mathrm{H}, \mathrm{CH}), 7.55\left(\mathrm{dd}, J_{5,6} 9 \mathrm{~Hz}, J_{5,7} 1 \mathrm{~Hz}, 2\right. \\
\mathrm{H}, \mathrm{CH}), 7.82\left(\mathrm{ddd}, J_{3,4} J_{3,2} 8 \mathrm{~Hz}, J_{3,1} 2 \mathrm{~Hz}, 1 \mathrm{H}, \mathrm{CH}\right), 8.54\left(\mathrm{ddd}, J_{4,3} 8 \mathrm{~Hz}, J_{4,2} J_{4,1} 1 \mathrm{~Hz}, 1 \mathrm{H}, \mathrm{CH}\right), 8.61\left(\mathrm{ddd}, J_{1,2} 5 \mathrm{~Hz}, J_{1,3} 2 \mathrm{~Hz}, J_{1,4} 1 \mathrm{~Hz}, 1\right. \\
\mathrm{H}, \mathrm{CH}), 10.21(\mathrm{~s}, 1 \mathrm{H}, \mathrm{NH}), 10.67(\mathrm{~s}, 1 \mathrm{H}, \mathrm{NH}) .\end{array}$ \\
\hline 1 & $\begin{array}{l}{ }^{1} \mathrm{H} \mathrm{NMR}\left(\mathrm{CD}_{2} \mathrm{Cl}_{2}\right) \delta 2.50\left(\mathrm{~s}, 3 \mathrm{H}, \mathrm{CH}_{3}\right), 5.97\left(\mathrm{~s}, 2 \mathrm{H}, \mathrm{NH}_{2}\right), 7.02\left(\mathrm{ddd}, J_{2,3} 8 \mathrm{~Hz}, J_{2,1} 5 \mathrm{~Hz}, J_{2,4} 2 \mathrm{~Hz}, 1 \mathrm{H}, \mathrm{CH}\right), 7.19\left(\mathrm{~d}, J_{1,2} 5 \mathrm{~Hz}, 1 \mathrm{H}, \mathrm{CH}\right), \\
7.49-7.74\left(\mathrm{~m}, 16 \mathrm{H}, \mathrm{PPh}_{3}+\mathrm{CH}\right), 8.01\left(\mathrm{ddd}, J_{3,2} 8 \mathrm{~Hz}, 1 \mathrm{H}\right) .\end{array}$ \\
\hline 2 & ${ }^{1} \mathrm{H} \mathrm{NMR}\left(\mathrm{CD}_{2} \mathrm{Cl}_{2}\right) \delta 2.52\left(\mathrm{~s}, 3 \mathrm{H}, \mathrm{CH}_{3}\right), 3.02\left(\mathrm{~s}, 3 \mathrm{H}, \mathrm{CH}_{3}\right), 6.95-8.05\left(\mathrm{~m}, 21 \mathrm{H}, \mathrm{PPh}_{3}+\mathrm{CH}\right)$. \\
\hline 3 & $\begin{array}{l}{ }^{1} \mathrm{H} \mathrm{NMR}\left(\mathrm{CD}_{2} \mathrm{Cl}_{2}\right) \delta 2.64\left(\mathrm{~s}, 3 \mathrm{H}, \mathrm{CH}_{3}\right), 7.04-7.14(\mathrm{~m}, 2 \mathrm{H}, \mathrm{CH}), 7.23\left(\mathrm{~d}, J_{7,6} 8 \mathrm{~Hz}, 1 \mathrm{H}, \mathrm{CH}\right), 7.34\left(\mathrm{t}, J_{5,6} 8 \mathrm{~Hz}, 2 \mathrm{H}, \mathrm{CH}\right), 7.49-7.73(\mathrm{~m}, 18 \\
\left.\mathrm{H}, \mathrm{PPh}_{3}+\mathrm{CH}\right), 7.85\left(\mathrm{~d}, J_{1,2} 8 \mathrm{~Hz}, 1 \mathrm{H}, \mathrm{CH}\right), 8.08\left(\mathrm{ddd}, J_{3,4} J_{3,2} 8 \mathrm{~Hz}, 1 \mathrm{H}, \mathrm{CH}\right) .\end{array}$ \\
\hline
\end{tabular}

\section{Crystal structure of the complexes}

Table 4 contains selected interatomic distances and angles for the complexes $\left[\mathrm{Pd}(\right.$ aptsc $\left.)\left(\mathrm{PPh}_{3}\right)\right]\left(\mathrm{NO}_{3}\right) \cdot \mathrm{H}_{2} \mathrm{O}$ (1), $\left[\mathrm{Pd}(\mathrm{apmtsc})\left(\mathrm{PPh}_{3}\right)\right]\left(\mathrm{NO}_{3}\right)(\mathbf{2})$ and $\left[\mathrm{Pd}(\right.$ apptsc $\left.)\left(\mathrm{PPh}_{3}\right)\right]$ $\left(\mathrm{NO}_{3}\right) \cdot \mathrm{H}_{2} \mathrm{O}(\mathbf{3})$. ORTEP drawings of the products, with an atomic numbering scheme, are shown in Figures 2, 3 and 4 , respectively.

All complexes are cationic, with a nitrate anion as counter ion. Products $\mathbf{1}$ and $\mathbf{3}$ also have a water molecule as solvate. In all complexes, the palladium(II) ion is in a quite similar, nearly planar, fourfold environment. The metal is coordinated to the negatively charged organic molecule through the pyridine nitrogen atom $[\mathrm{Pd}-\mathrm{N}$ bond distances of 210.2(3) pm for 1, 210.1(3) pm for $\mathbf{2}$ and 208.8(2) pm for 3], the azomethine $\mathrm{N}$-atom [at slightly shorter $\mathrm{Pd}-\mathrm{N}$ distances of 202.4(3), 203.2(3) and 200.6(2) pm for 1, 2 and $\mathbf{3}$, respectively] and the sulfur atom [Pd-S distances of 225.36(9), 225.15(11) and 224.07(7) pm for 1, 2 and 3, respectively]. This forms two five-membered chelate rings including the $\mathrm{Pd}^{\mathrm{II}}$ atom and with bond dimensions comparable to those observed for similar square-planar $\mathrm{Pd}^{\mathrm{II}}$ complexes. ${ }^{11,29}$ The remaining binding site is occupied by a phosphorous atom [Pd-P distances of 229.39(8), 229.23(9) and 227.57(7) pm for 1, 2 and $\mathbf{3}$, respectively].

The stronger coordination of the metal to the azomethine nitrogen compared to the pyridyl nitrogen is attributed to the higher basicity of $\mathrm{N}(2) .{ }^{18}$ The largest deviation in the bond angles from those expected for square planarity is found for the angle $\mathrm{N}(1)-\mathrm{Pd}-\mathrm{S}$, in which an average deviation, considering the three complexes, is of $16.7^{\circ}$ below the expected value of $180^{\circ}$.

In complex $\mathbf{1}$, the crystal structure is stabilized by a net of intermolecular hydrogen bonds toward the direction [001], parallel to the $c$ axis, which is shown in Figure S1
Table 4. Selected bond lengths (pm) and angles $\left({ }^{\circ}\right)$ refined from X-ray data for 1-3

\begin{tabular}{lccc}
\hline & $\mathbf{1}$ & $\mathbf{2}$ & $\mathbf{3}$ \\
\hline Bond Lengths & & & \\
\hline $\mathrm{Pd}-\mathrm{N}(1)$ & $210.2(3)$ & $210.1(3)$ & $208.8(2)$ \\
$\mathrm{Pd}-\mathrm{N}(2)$ & $202.4(3)$ & $203.2(3)$ & $200.6(2)$ \\
$\mathrm{Pd}-\mathrm{S}$ & $225.36(9)$ & $225.15(11)$ & $224.07(7)$ \\
$\mathrm{Pd}-\mathrm{P}$ & $229.39(8)$ & $229.23(9)$ & $227.57(7)$ \\
$\mathrm{S}-\mathrm{C}(8)$ & $177.6(4)$ & $176.8(4)$ & $176.7(3)$ \\
$\mathrm{N}(3)-\mathrm{N}(2)$ & $136.7(4)$ & $136.3(4)$ & $137.0(3)$ \\
$\mathrm{P}-\mathrm{C}(11)$ & $181.8(3)$ & $182.4(4)$ & $182.3(3)$ \\
$\mathrm{P}-\mathrm{C}(21)$ & $182.9(3)$ & $181.0(3)$ & $180.9(3)$ \\
$\mathrm{P}-\mathrm{C}(31)$ & $182.6(3)$ & $182.7(4)$ & $181.5(3)$ \\
$\mathrm{N}(5)-\mathrm{O}(1)$ & $115.5(6)$ & $114.0(7)$ & $121.6(4)$ \\
$\mathrm{N}(5)-\mathrm{O}(2)$ & $118.4(6)$ & $121.8(8)$ & $123.9(4)$ \\
$\mathrm{N}(5)-\mathrm{O}(3)$ & $127.6(7)$ & $119.9(9)$ & $120.2(4)$ \\
\hline Bond Angles & & & \\
\hline $\mathrm{N}(2)-\mathrm{Pd}-\mathrm{N}(1)$ & $79.54(11)$ & $79.43(12)$ & $79.62(8)$ \\
$\mathrm{N}(2)-\mathrm{Pd}-\mathrm{S}$ & $83.55(9)$ & $83.87(9)$ & $84.22(6)$ \\
$\mathrm{N}(1)-\mathrm{Pd}-\mathrm{S}$ & $162.88(8)$ & $163.29(9)$ & $163.67(6)$ \\
$\mathrm{N}(2)-\mathrm{Pd}-\mathrm{P}$ & $174.95(8)$ & $177.64(9)$ & $175.82(6)$ \\
$\mathrm{N}(1)-\mathrm{Pd}-\mathrm{P}$ & $102.86(7)$ & $102.80(9)$ & $102.13(6)$ \\
$\mathrm{S}-\mathrm{Pd}-\mathrm{P}$ & $94.20(3)$ & $93.90(4)$ & $93.84(3)$ \\
$\mathrm{C}(8)-\mathrm{S}-\mathrm{Pd}$ & $95.89(13)$ & $95.81(14)$ & $95.48(9)$ \\
$\mathrm{C}(1)-\mathrm{N}(1)-\mathrm{Pd}$ & $130.9(2)$ & $130.7(3)$ & $130.1(2)$ \\
$\mathrm{C}(5)-\mathrm{N}(1)-\mathrm{Pd}$ & $110.8(2)$ & $111.2(2)$ & $111.2(2)$ \\
$\mathrm{C}(8)-\mathrm{N}(3)-\mathrm{N}(2)$ & $112.2(3)$ & $112.5(3)$ & $111.4(2)$ \\
$\mathrm{C}(6)-\mathrm{N}(2)-\mathrm{Pd}$ & $117.1(2)$ & $116.8(3)$ & $117.8(2)$ \\
$\mathrm{N}(3)-\mathrm{N}(2)-\mathrm{Pd}$ & $123.2(2)$ & $122.5(2)$ & $123.1(2)$ \\
\hline & & &
\end{tabular}

(Supplementary Information, SI). The nitrogen atom N(4), of the $\mathrm{NH}_{2}$ group, is $\mathrm{H}$-bonded through $\mathrm{H}(41)$ to the $\mathrm{O}(2)$ atom from a nitrate ion, while $\mathrm{H}(42)$ interacts with a hydrate water oxygen atom, $\mathrm{O}(4)$. Furthermore, the oxygen atom $\mathrm{O}(4)$ is $\mathrm{H}$-bonded through $\mathrm{H}(4 \mathrm{a})$ to the $\mathrm{O}(1 \mathrm{~b})$ and $\mathrm{O}(3 \mathrm{~b})$ from a symmetry-generated nitrate ion and through $\mathrm{H}(4 \mathrm{~b})$ to the 


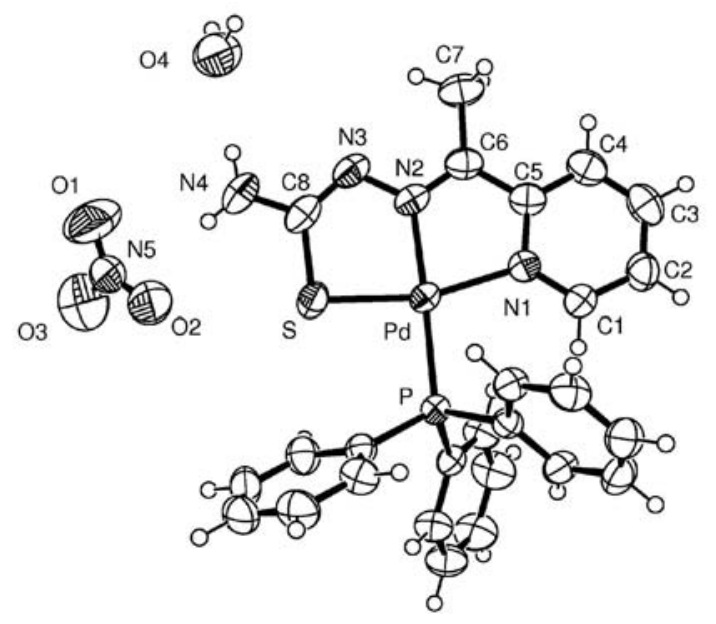

Figure 2. An ORTEP view of $\left[\mathrm{Pd}(\mathrm{aptsc})\left(\mathrm{PPh}_{3}\right)\right]\left(\mathrm{NO}_{3}\right) \cdot \mathrm{H}_{2} \mathrm{O}(\mathbf{1})$ with the thermal ellipsoids at the $50 \%$ probability level. The labeling scheme used for the phenyl rings is omitted for clarity.

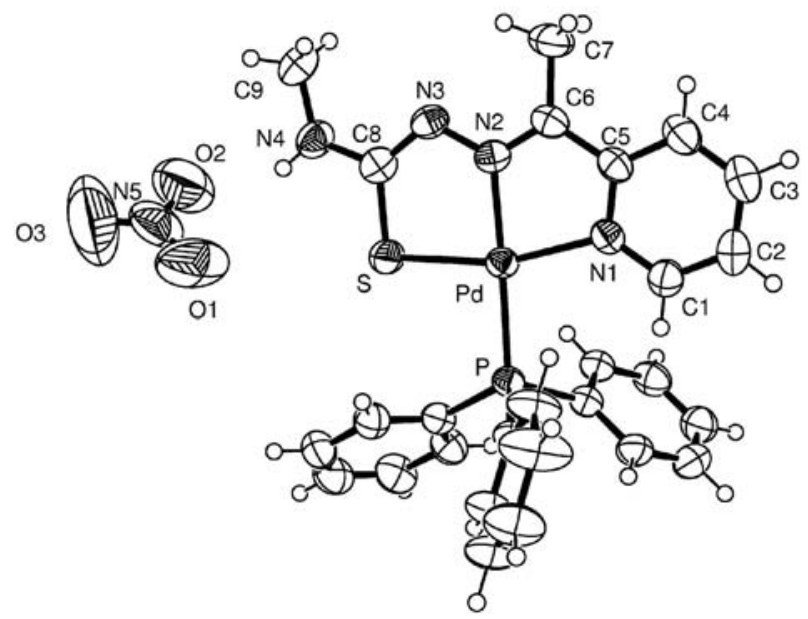

Figure 3. An ORTEP view of $\left[\mathrm{Pd}(\mathrm{apmtsc})\left(\mathrm{PPh}_{3}\right)\right]\left(\mathrm{NO}_{3}\right)$ (2) with the thermal ellipsoids at the $50 \%$ probability level. The labeling scheme used for the phenyl rings is omitted for clarity.

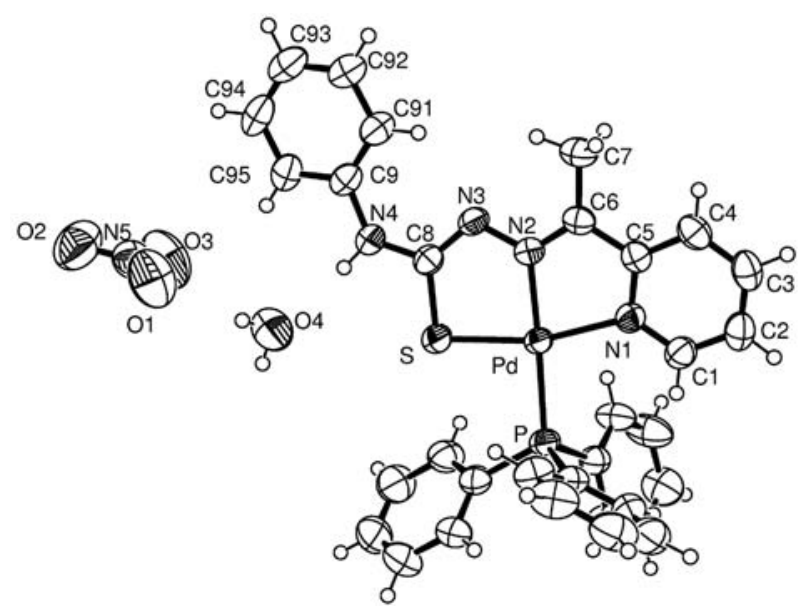

Figure 4. An ORTEP view of $\left[\mathrm{Pd}(\right.$ apptsc $\left.)\left(\mathrm{PPh}_{3}\right)\right]\left(\mathrm{NO}_{3}\right) \cdot \mathrm{H}_{2} \mathrm{O}(3)$ with the thermal ellipsoids at the $50 \%$ probability level. The labeling scheme used for the phenyl rings is omitted for clarity.
$\mathrm{N}$ (3a) atom from a symmetry-related complex molecule. The crystalline structure of complex $\mathbf{2}$ is stabilized by hydrogen interactions involving the nitrogen atom $\mathrm{N}(4)$ and the oxygen atoms $\mathrm{O}(2)$ and $\mathrm{O}(1)$, as shown in Figure S2. As observed in $\mathbf{2}$, the crystal structure of complex $\mathbf{3}$ is also stabilized by hydrogen bonds, but in a different mode. The nitrogen atom $\mathrm{N}(4)$ is H-bonded through $\mathrm{H}(41)$ to a symmetry generated oxygen atom $\mathrm{O}(4 \mathrm{~b})$ from a hydrate water molecule, while the same oxygen $\mathrm{O}(4)$ atom is $\mathrm{H}$-bonded through $\mathrm{H}(411 \mathrm{~b})$ to the oxygen atom $\mathrm{O}(1 \mathrm{~b})$ of a nitrate ion, as shown in Figure S3. The distances, angles and symmetry operations related to the hydrogen bonds are given in Table S1.

\section{Cytotoxic activity}

The palladium(II) complexes and the respective free thiosemicarbazones were evaluated for their effectiveness against the breast tumor cell line MDA-MB231. For comparison purposes, the cytotoxicity of cisplatin was evaluated under the same experimental conditions. The values of cell viability were calculated after the tested compounds were incubated for $48 \mathrm{~h}$ (Figure 5). The $\mathrm{IC}_{50}$ values, calculated from the dose-survival curves from MTT assay, are shown in Table 5.

Comparing only the values of $\mathrm{IC}_{50}$ of the free thiosemicarbazones, the order of cytotoxic activity was Happtsc > Hapmtsc > Haptsc, suggesting that the activity is increased by the presence of bulky groups bonded to

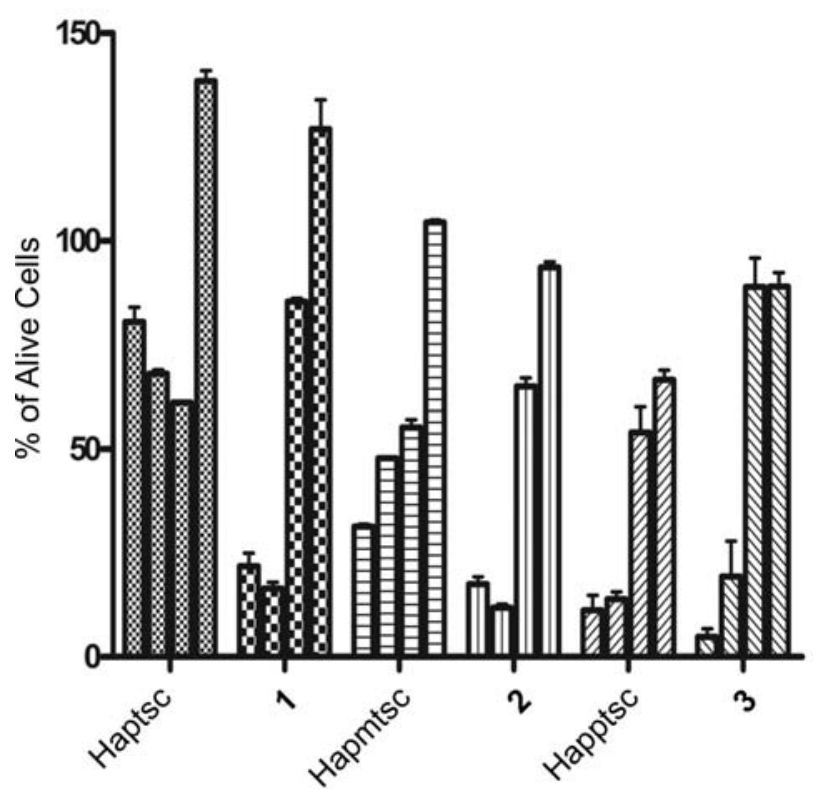

Figure 5. The effect of the thiosemicarbazones and their Pd" complexes on the viability of MDA-MB-231 cells. Cell proliferation was determined after 2 days of culturing in the presence of different concentrations of tested compounds and estimated by colorimetric assay (MTT) as described in Experimental section. The data represent a mean of three independent experiments \pm SD. [ ]/( $\left.\mu \mathrm{mol} \mathrm{L}{ }^{-1}\right)=200 / 20 / 2 / 0.2$. 
Table 5. $\mathrm{IC}_{50}$ values of the thiosemicarbazones, $\mathrm{Pd}^{\mathrm{II}}$ complexes and cisplatin against breast tumor MDA-MB-231 cell line and the MIC values against the strains of the Mycobacterium tuberculosis $\mathrm{H}_{37} \mathrm{Rv}$ ATCC 27294

\begin{tabular}{lccc}
\hline & $\mathrm{IC}_{50}(\mu \mathrm{mol} \mathrm{L}$ \\
& $>200$ & $\mathrm{MIC}\left(\mu \mathrm{g} \mathrm{mL}^{-1}\right)$ & $\mathrm{MIC}\left(\mu \mathrm{mol} \mathrm{L}^{-1}\right)$ \\
\hline Haptsc* & $4.9 \pm 0.9$ & 12.5 & 160.9 \\
$\mathbf{1}$ & $24.6 \pm 11.3$ & 7.8 & 19.5 \\
Hapmtsc & $5.2 \pm 1.5$ & 25 & 37.4 \\
$\mathbf{2}$ & $2.8 \pm 0.5$ & 15.6 & 39.2 \\
Happtsc & $5.5 \pm 2.8$ & 6.25 & 57.7 \\
$\mathbf{3}$ & $>200$ & Not measured & Not measured \\
Cisplatin* & $>200$ & $>50$ & - \\
{$\left[\mathrm{PdCl}_{2}\left(\mathrm{MeCN}_{2}\right]\right.$} & Not soluble & $>50$ & - \\
{$\left[\mathrm{PdCl}_{2}\left(\mathrm{PPh}_{3}\right)_{2}\right]$} & Not measured & 0.015 & 0.1 \\
Isoniazid & &
\end{tabular}

*The maximum concentration employed in cytotoxicity tests was $200 \mu \mathrm{mol} \mathrm{L}{ }^{-1}$.

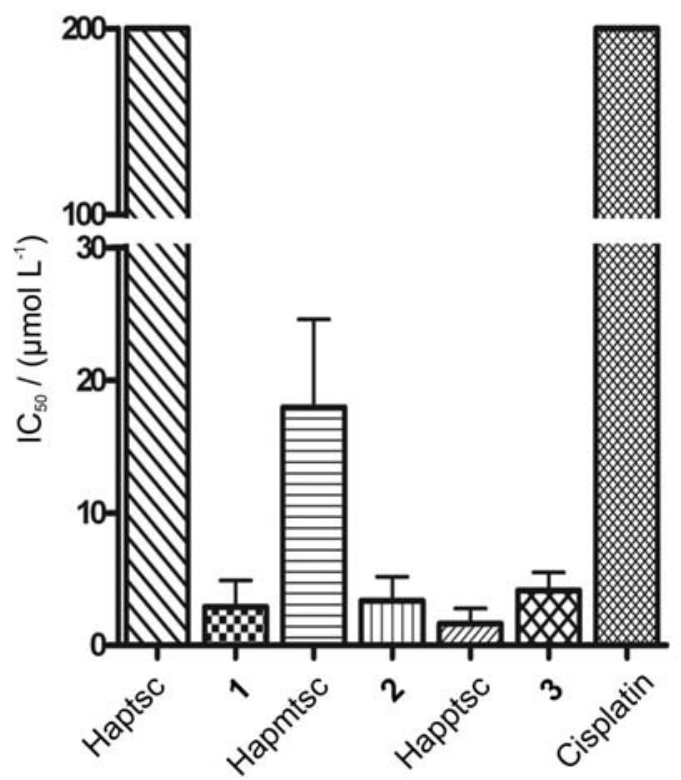

Figure 6. Comparison of the magnitude of the $\mathrm{IC}_{50}$ values of cisplatin, free thiosemicarbazones and the respective $\mathrm{Pd}^{\mathrm{II}}$ complexes against breast tumor MDA-MB-231 cell line.

$\mathrm{N}(4)$ of the thiosemicarbazone. On the other hand, all palladium complexes presented values of $\mathrm{IC}_{50}$ around $5 \mu \mathrm{mol} \mathrm{L}{ }^{-1}$, showing no significant variation on the activity due to the changes in the groups bonded to the $\mathrm{N}(4)$ of the thiosemicarbazone ligands. The palladium complexes were more active than the free thiosemicarbazones, except for complex 3, whose thiosemicarbazone precursor Happtsc had an $\mathrm{IC}_{50}$ value around $3 \mu \mathrm{mol} \mathrm{L} \mathrm{L}^{-1}$. The palladium complex 2 presented an activity five times higher than that from Hapmtsc. In addition, the Haptsc and cisplatin were ineffective against the tested cell line, with the $\mathrm{IC}_{50}$ value over $200 \mu \mathrm{mol} \mathrm{L}^{-1}$. A comparison with the precursor compound $\left[\mathrm{PdCl}_{2}\left(\mathrm{PPh}_{3}\right)_{2}\right]$ was not possible due to the lack of solubility in dmso, even at the concentration of $2 \mu \mathrm{mol} \mathrm{L}{ }^{-1}$. Alternatively, $\left[\mathrm{PdCl}_{2}(\mathrm{MeCN})_{2}\right]$ and $\mathrm{PPh}_{3}$ were tested, showing no activity at the concentration of $200 \mu \mathrm{mol} \mathrm{L}{ }^{-1}$. The good values of activity found for these complexes, around $5.0 \mu \mathrm{mol} \mathrm{L}^{-1}$, show that the complexation of thiosemicarbazone to $\mathrm{Pd}^{\mathrm{II}}$ may be a good strategy to obtain antitumor agents, although in this case the free Happtsc presented the best result.

The similarity of the values of $\mathrm{IC}_{50}$ found for the $\mathrm{Pd}^{\mathrm{II}}$ complexes is an evidence in favor of the same biochemical action mechanism, but different from those of the cisplatin, inactive in this case, and of the free thiosemicarbazones, which varied from inactive (Haptsc) to a significant activity (Happtsc). In fact, the literature reports that palladium(II) and platinum(II) complexes of thiosemicarbazone derivatives are able to bind to DNA in vitro, and present enhanced capacity to form interstrand crosslinks when compared to cisplatin. ${ }^{30,31}$ Additionally, the presence of a phosphine ligand may also contribute to higher activity. ${ }^{32}$

On the other hand, the free thiosemicarbazones could present antitumor effect by inhibiting DNA syntheses through the blockage of the enzyme ribonucleoside diphosphate reductase (RDR), which catalyses the conversion of ribonucleotides into desoxyribonucleotides, as proposed for other $\alpha(N)$-heterocyclic thiosemicarbazones. ${ }^{33}$

\section{Anti-Mycobacterium tuberculosis activity}

The in vitro antimycobacterial activities of the three thiosemicarbazones and their $\mathrm{Pd}^{\mathrm{II}}$ complexes were assessed against the strains of the Mycobacterium tuberculosis $\mathrm{H}_{37} \mathrm{Rv}$ ATCC 27294. The results are exposed in Table 5.

Comparing the MIC values of the free thiosemicarbazones with the values obtained for the complexes, it can be seen that, except for $\mathbf{2}$, the activity of the complexes is much higher than those of the uncoordinated thiosemicarbazones. Complexes $\mathbf{1}$ and $\mathbf{3}$ present approximately 8-fold and 6-fold higher activities, respectively, than the respective free thiosemicarbazones.

The activity found for complex $\mathbf{3}$ is comparable to those of some commonly used anti-M. tuberculosis agents, like cycloserine $\left(\mathrm{MIC}=122.4-489.7 \mu \mathrm{mol} \mathrm{L}^{-1}\right.$ ), gentamicin $\left(\mathrm{MIC}=4.19-8.38 \mu \mathrm{mol} \mathrm{L}^{-1}\right)$, tobramycin $\left(\mathrm{MIC}=8.56-17.11 \mu \mathrm{mol} \mathrm{L}^{-1}\right)$ and clarithromycin $\left(\mathrm{MIC}=10.70-21.40 \mu \mathrm{mol} \mathrm{L}{ }^{-1}\right) .{ }^{27}$ The precursor complex, $\left[\mathrm{PdCl}_{2}\left(\mathrm{PPh}_{3}\right)_{2}\right]$, as well as the complex $\left[\mathrm{PdCl}_{2}(\mathrm{MeCN})_{2}\right]$, did not show any inhibition at the concentration of $50 \mu \mathrm{g} \mathrm{mL} \mathrm{m}^{-1}$, corresponding to 71.2 and $192.8 \mu \mathrm{mol} \mathrm{L} \mathrm{L}^{-1}$, respectively, suggesting that the thiosemicarbazonate 
ligands are the active species and that their activity may be improved upon complexation to palladium. Previous studies explain this fact as a result of the polarity reduction of the complex molecule as a whole, when compared with the free ions or complexing agents, by partial sharing of their charges within the coordination compounds, favoring their permeation through the lipid layer of the cell membrane, hence resulting in a better cell uptake of the active species. ${ }^{34-37}$

\section{Conclusions}

A series of thiosemicarbazones was used to prepare novel cationic $\left[\mathrm{Pd}^{\mathrm{I}} \mathrm{L}\left(\mathrm{PPh}_{3}\right)\right]^{+}$complexes with nitrate as counter ion (1-3). The X-ray studies revealed square-planar structures in which the thiosemicarbazonate ligands bind in a tridentate monoanionic mode (with loss of the $\mathrm{N}(3)$ hydrogen atom) by coordination to palladium through the pyridine $\mathrm{N}$, azomethine $\mathrm{N}$ and thiolate $\mathrm{S}$ atoms. The fourth coordination site is occupied by neutral $\mathrm{PPh}_{3}$. The crystal structure of $\mathbf{1}$ presents a supramolecular network generated by intermolecular hydrogen bonds, while in the structures of $\mathbf{2}$ and $\mathbf{3}$ only local hydrogen bonds between the cationic molecule and a nitrate counter ion are observed. Comparing only the values of $\mathrm{IC}_{50}$ of the free thiosemicarbazones, it was observed that the activity is increased by the presence of bulky groups bonded to N(4). All palladium(II) complexes were effective against the studied tumoral cell line, presenting high antiproliferative effect, with $\mathrm{IC}_{50}$ values around $5 \mu \mathrm{mol} \mathrm{L}{ }^{-1}$, while the clinically applied antitumor agent cisplatin and the precursor compound $\left[\mathrm{PdCl}_{2}\left(\mathrm{PPh}_{3}\right)_{2}\right]$ were ineffective. The similarity of the $\mathrm{IC}_{50}$ values for the $\mathrm{Pd}^{\mathrm{II}}$ complexes indicates that they may have the same biochemical action mechanism, other than those of the cisplatin and the thiosemicarbazones. The complexes $\mathbf{1}$ and 3 show higher anti- $M$. tuberculosis activities, compared to the free thiosemicarbazones, and their actions are equivalent or greater than those of some commercial anti- $M$ tuberculosis drugs.

\section{Supplementary Information}

Crystallographic data have been deposited with the Cambridge Crystallographic Data Centre (deposition numbers CCDC 743883, CCDC 743884 and CCDC 743885 for complexes $\mathbf{1}, \mathbf{2}$ and $\mathbf{3}$, respectively). Copies of available material can be obtained by request to CCDC, 12 Union Road, Cambridge CB2 1EZ, UK (fax 44-1223336033 or e-mail: deposit@ccdc.cam.ac.uk). Table S1 and Figures S1, S2 and S3 are available free of charge at http://jbcs.sbq.org.br.

\section{Acknowledgments}

The authors gratefully acknowledge the financial support of FAPESP, CAPES, CNPq and FINEP.

\section{References}

1. Genova, P.; Varadinova, T.; Matesanz, A. I.; Marinova, D.; Souza, P.; Toxicol. Appl. Pharmacol. 2004, 197, 107.

2. Kelland, L. R.; Crit. Rev. Oncol. Hematol. 1993, 15, 191.

3. Kelland, L. R.; Sharp, S. Y.; ÓNeill, C. F.; Raynaud, F. I.; Beale, P. J.; Judson, I. R.; J. Inorg. Biochem. 1999, 77, 111.

4. Tripathi, R. P.; Tewari, N.; Dwivedi, N.; Tiwari, V. K.; Med. Res. Rev. 2005, 25, 93.

5. Sriram, D.; Yogeeswari, P.; Thirumurugan, R.; Bioorg. Med. Chem. Lett. 2004, 14, 3923.

6. Lebwohl, D.; Canetta, R.; Eur. J. Cancer 1998, 34, 1522.

7. Padhye, S. B.; Kauffman, G. B.; Coord. Chem. Rev. 1985, 63, 127.

8. Miernicka, M.; Szulawska, A.; Czyz, M.; Lorenz, I.-P.; Mayer, P.; Karwowski, B.; Budzisz, E.; J. Inorg. Biochem. 2008, 102, 157.

9. Pérez, J. M.; Matesanz, A. I.; Martín-Ambite, A.; Navarro, P.; Alonso, C.; Souza, P.; J. Inorg. Biochem. 1999, 75, 255.

10. Nomiya, K.; Sekino, K.; Ishikawa, M.; Honda, A.; Yokoyama, M.; Kasuga, N. C.; Yokoyama, H.; Nakano, S.; Onodera, K.; J. Inorg. Biochem. 2004, 98, 601.

11. Kovala-Demertzi, D.; Domopoulou, A.; Demervzis, M. A.; Valle, G.; Papageorgiou, A.; J. Inorg. Biochem. 1997, 68, 147.

12. Maia, P. I. S.; Deflon, V. M.; Sousa, G. F.; Batista, A. A.; Nascimento, O. R.; Niquet, E.; Z. Anorg. Allg. Chem. 2007, 633, 783 .

13. Cocco, M. T.; Congiu, C.; Onnis, V.; Pellerano, M. L.; Logu, A. D.; Bioorg. Med. Chem. 2002, 10, 501.

14. do Nascimento, F. B.; Poelhsitz, G. V.; Pavan, F. R.; Sato, D. N.; Leite, C. Q. F.; Selistre-de-Araújo, H. S.; Ellena, J.; Castellano, E. E.; Deflon, V. M.; Batista, A. A.; J. Inorg. Biochem. 2008, 102, 1783.

15. Rodríguez-Argüelles, M. C.; López-Silva, E. C.; Sanmartín, J.; Pelagatti, P.; Zani, F.; J. Inorg. Biochem. 2005, 99, 2231.

16. Sau, D. K.; Butcher, R. J.; Chaudhuri, S.; Saha, N.; Mol. Cell. Biochem. 2003, 253, 21.

17. Matesanz, A. I.; Perez, J. M.; Navarro, P.; Moreno, J. M.; Colacio, E.; Souza, P.; J. Inorg. Biochem. 1999, 76, 29.

18. Kovala-Demertzi, D.; Demertzis, M. A.; Miller, J. R.; Papadopoulou, C.; Dodorou, C.; Filousis, G.; J. Inorg. Biochem. 2001, 86, 555.

19. Jalilian, A. R.; Sadeghi, M.; Kamrani, Y. Y.; Radiochim. Acta 2006, 94, 865.

20. Padhye, S.; Afrasiabi, Z.; Sinn, E.; Fok, J.; Mehta, K.; Rath, N.; Inorg. Chem. 2005, 44, 1154. 
21. Bharti, N.; Athar, F.; Maurya, M. R.; Azam, A.; Bioorg. Med. Chem. 2004, 12, 4679.

22. Queiroz, S. L.; Batista, A. A.; Quim. Nova 1996, 19, 651.

23. Klayman, D. L.; Bartosevich, J. F.; Griffin, T. S.; Mason, C. J.; Scovill, J. P.; J. Med. Chem. 1979, 22, 855.

24. Sheldrick, G. M.; SHELXS97, Program for the Solution of Crystal Structures, University of Göttingen, Germany, 1997.

25. Sheldrick, G. M.; SHELXL97, Program for the Refinement of Crystal Structures, University of Göttingen, Germany, 1997.

26. Mosmann, T.; J. Immunol. Methods 1983, 65, 55.

27. Franzblau, S. G.; Witzig, R. S.; McLaughlin, J. C.; Torres, P.; Madico, G.; Hernandez, A.; Degnan, M. T.; Cook, M. B.; Quenzer, V. K.; Ferguson, R. M.; Gilman, R. H.; J. Clin. Microbiol. 1998, 36, 362.

28. Collins, L. A.; Franzblau, S. G.; Antimicrob. Agents Chemother. 1997, 41, 1004.

29. Rebolledo, A. P.; Vieites, M.; Gambino, D.; Piro, O. E.; Castellano, E. E.; Zani, C. L.; Souza-Fagundes, E. M.; Teixeira, L. R.; Batista, A. A.; Beraldo, H.; J. Inorg. Biochem. 2005, 99, 698.

30. Quiroga, A. G.; Navarro-Ranninger, C.; Coord. Chem. Rev. 2004, 248, 119.

31. Quiroga, A. G.; Perez, J. M.; Montero, E. I.; Masaguer, J. R.; Alonso, C.; Navarro-Ranninger, C.; J. Inorg. Biochem. 1998, $70,117$.
32. da Rocha, M. C.; Santana, A. M.; Ananias, S. R.; de Almeida, E. T.; Mauro, A. E.; Placeresa, M. C. P.; Carlos, I. Z.; J. Braz. Chem. Soc. 2007, 18, 1473.

33. Cory, J. G.; Cory, A. H.; Rappa, G.; Lorico, A.; Liu, M.; Lin, T.; Sartorelli, A. C.; Biochem. Pharmacol. 1994, 48, 335.

34. Maia, P. I. S.; Pavan, F. R.; Leite, C. Q. F.; Lemos, S. S.; de Sousa, G. F.; Batista, A. A.; Nascimento, O. R.; Ellena, J.; Castellano, E. E.; Niquet, E.; Deflon, V. M.; Polyhedron 2009, $28,398$.

35. Maurya, M. R.; Kumar, A.; Abid, M.; Azam, A.; Inorg. Chim. Acta 2006, 359, 2439.

36. Mendes, I. C.; Moreira, J. P.; Speziali, N. L.; Mangrich, A. S.; Takahashia, J. A.; Beraldo, H.; J. Braz. Chem. Soc. 2006, 17, 1571.

37. Maurya, M. R.; Kumar, A.; Bhat, A. R.; Azam, A.; Bader, C.; Rehder, D. Inorg. Chem. 2006, 45, 1260.

Received: August 14, 2009

Web Release Date: February 25, 2010

FAPESP helped in meeting the publication costs of this article. 


\title{
Palladium(II) Complexes with Thiosemicarbazones. Syntheses, Characterization, Cytotoxicity against Breast Cancer Cells and Anti-Mycobacterium tuberculosis Activity
}

\author{
Pedro I. da S. Maia, ${ }^{a}$ Angélica Graminha, ${ }^{b}$ Fernando R. Pavan, ${ }^{c}$ Clarice Q. F. Leite, ${ }^{c}$ \\ Alzir A. Batista, ${ }^{b}$ Davi F. Back, ${ }^{d}$ Ernesto S. Lang, ${ }^{d}$ Javier Ellena, ${ }^{e}$ Sebastião de S. Lemos, ${ }^{f}$ \\ Heloisa S. Salistre-de-Araujo ${ }^{g}$ and Victor M. Deflon*,a \\ ${ }^{a}$ Instituto de Química de São Carlos, Universidade de São Paulo, 13566-590 São Carlos - SP, Brazil \\ ${ }^{b}$ Departamento de Química, Universidade Federal de São Carlos, 13565-905 São Carlos - SP, Brazil \\ ${ }^{c}$ Faculdade de Ciências Farmacêuticas, Universidade Estadual Paulista, 14801-902 Araraquara - SP, Brazil \\ ${ }^{d}$ Departamento de Química, Universidade Federal de Santa Maria, 97105-900 Santa Maria - RS, Brazil \\ ${ }^{e}$ Instituto de Física de São Carlos, Universidade de São Paulo, 13560-970 São Carlos - SP, Brazil \\ ${ }^{f}$ Instituto de Química, Universidade de Brasília, 70919-970 Brasília - DF, Brazil \\ ${ }^{g}$ Departamento de Ciências Fisiológicas, Universidade Federal de São Carlos, 13565-905 São Carlos - SP, Brazil
}

Table S1. Hydrogen bonds (distances in pm and angles in ${ }^{\circ}$ ) for complexes 1-3, calculated for distances d $(\mathrm{H} \cdots \mathrm{A})<\mathrm{r}(\mathrm{A})+200.0 \mathrm{pm}$ and angles $\angle(\mathrm{D}-\mathrm{H} \cdots \mathrm{A})>110^{\circ}(\mathrm{D}=\mathrm{H}-$ donor, $\mathrm{A}=\mathrm{H}$-acceptor $)$

\begin{tabular}{|c|c|c|c|c|}
\hline $\mathrm{D}-\mathrm{H} \cdots \mathrm{A}$ & $\mathrm{d}(\mathrm{H} \cdots \mathrm{A})$ & $\angle(\mathrm{D}-\mathrm{H} \cdots \mathrm{A})$ & $\mathrm{d}(\mathrm{D} \cdots \mathrm{A})$ & Symmetry operation \\
\hline \multicolumn{5}{|l|}{ Complex 1} \\
\hline $\mathrm{N}(4)-\mathrm{H}(41 \mathrm{a}) \cdots \mathrm{O}(4)$ & 205.3 & 177.69 & 291.2 & \\
\hline $\mathrm{N}(4)-\mathrm{H}(41 \mathrm{~b}) \cdots \mathrm{O}(2)$ & 223.1 & 151.91 & 301.7 & \\
\hline $\mathrm{O}(4)-\mathrm{H}(4 \mathrm{a}) \cdots \mathrm{O}(1)$ & 231.7 & 150.42 & 309.1 & $-x+3,-y+1,-z+1$ \\
\hline $\mathrm{O}(4)-\mathrm{H}(4 \mathrm{a}) \cdots \mathrm{O}(3)$ & 242.8 & 155.95 & 322.9 & $-\mathrm{x}+3,-\mathrm{y}+1,-\mathrm{z}+1$ \\
\hline $\mathrm{O}(4)-\mathrm{H}(4 \mathrm{~b}) \cdots \mathrm{N}(3)$ & 256.1 & 135.37 & 328.2 & $-\mathrm{x}+2,-\mathrm{y}+1,-\mathrm{z}+1$ \\
\hline \multicolumn{5}{|l|}{ Complex 2} \\
\hline $\mathrm{N}(4)-\mathrm{H}(41) \cdots \mathrm{O}(1)$ & 259.2 & 145.41 & 333.6 & \\
\hline $\mathrm{N}(4)-\mathrm{H}(41) \cdots \mathrm{O}(2)$ & 206.5 & 149.85 & 284.2 & \\
\hline \multicolumn{5}{|l|}{ Complex $\mathbf{3}$} \\
\hline $\mathrm{O}(4 \mathrm{~b})-\mathrm{H}(411 \mathrm{~b}) \cdots \mathrm{O}(1 \mathrm{~b})$ & 214.9 & 135.67 & 282.0 & $\mathrm{x}-1, \mathrm{y}, \mathrm{z}$ \\
\hline $\mathrm{N}(4)-\mathrm{H}(41) \cdots \mathrm{O}(4 \mathrm{~b})$ & 206.1 & 162.88 & 289.4 & $\mathrm{x}-1, \mathrm{y}, \mathrm{z}$ \\
\hline
\end{tabular}




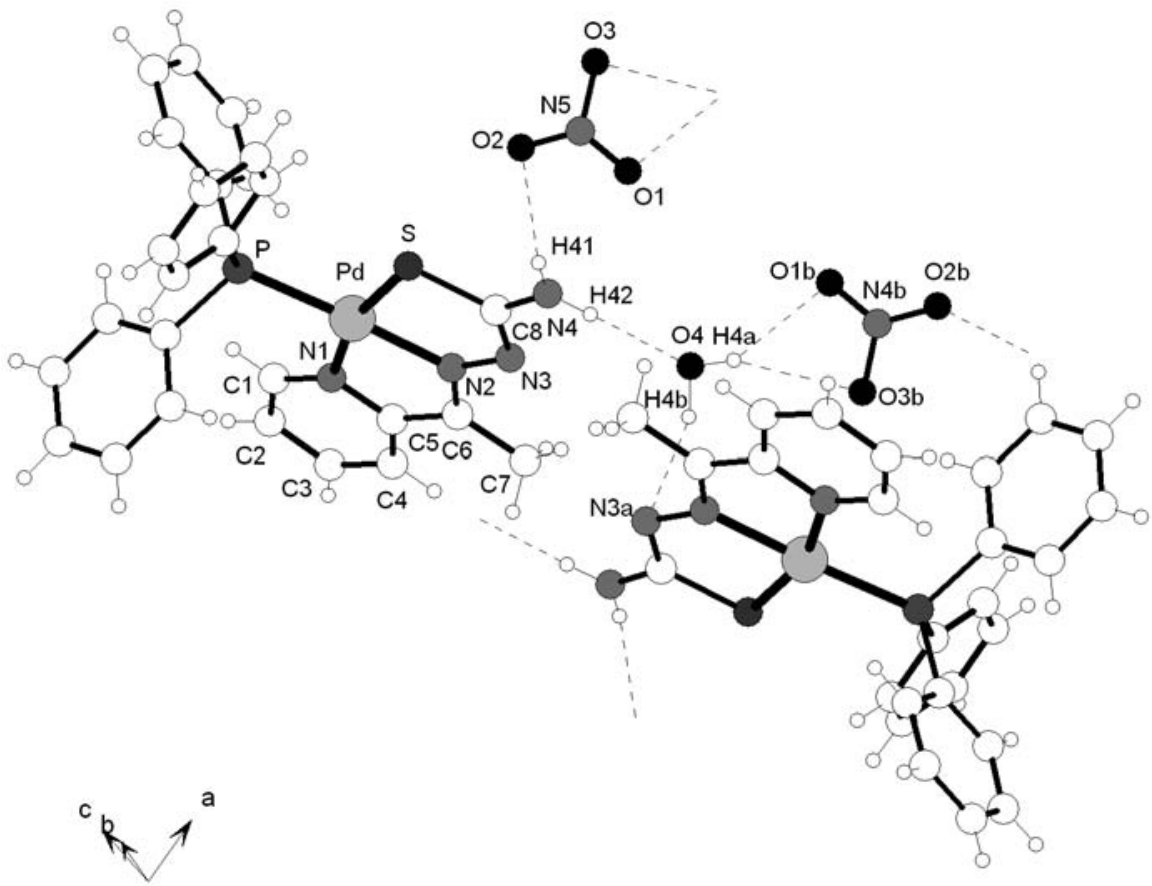

Figure S1. View of the crystal structure of $\left[\mathrm{Pd}(\mathrm{aptsc})\left(\mathrm{PPh}_{3}\right)\right]\left(\mathrm{NO}_{3}\right) \cdot \mathrm{H}_{2} \mathrm{O}(\mathbf{1})$ toward the direction [001], showing the hydrogen bonds as dashed lines.

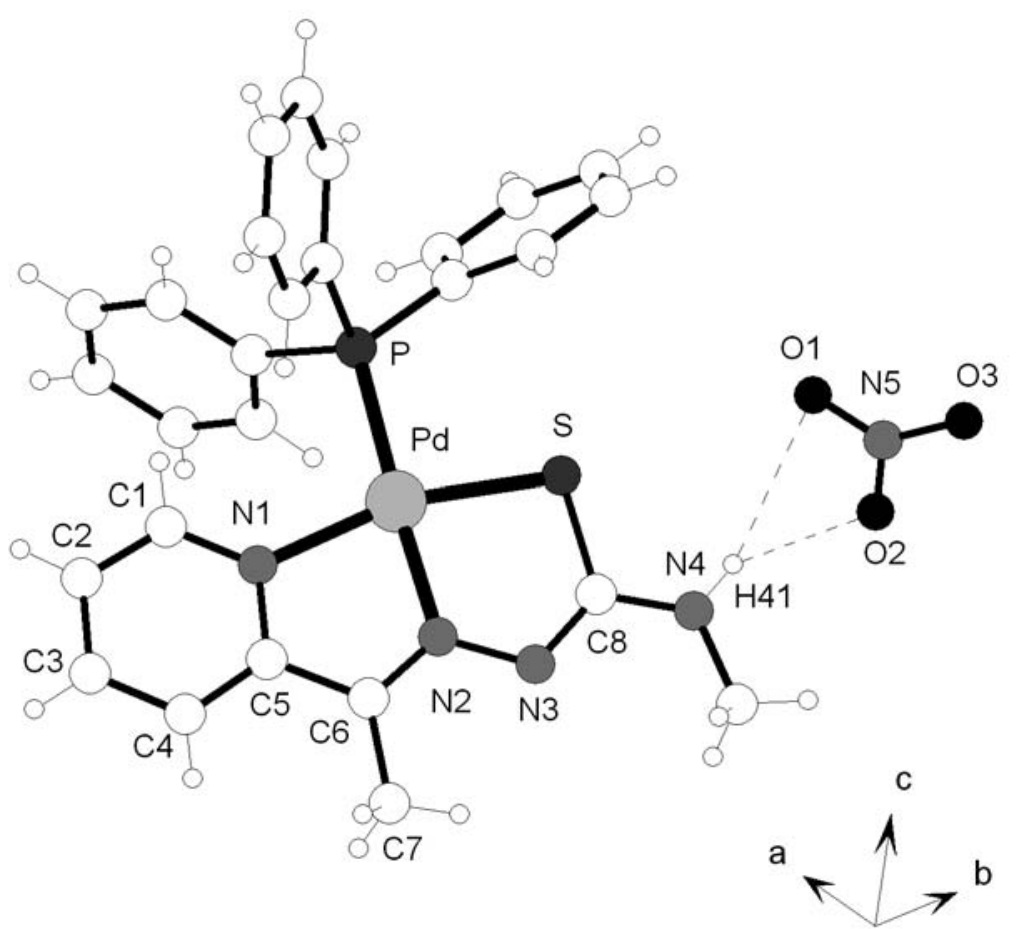

Figure S2. View of the crystal structure of $\left[\mathrm{Pd}(\operatorname{apmtsc})\left(\mathrm{PPh}_{3}\right)\right]\left(\mathrm{NO}_{3}\right)(\mathbf{2})$ parallel to the plane $a b$, showing the hydrogen bonds as dashed lines. 


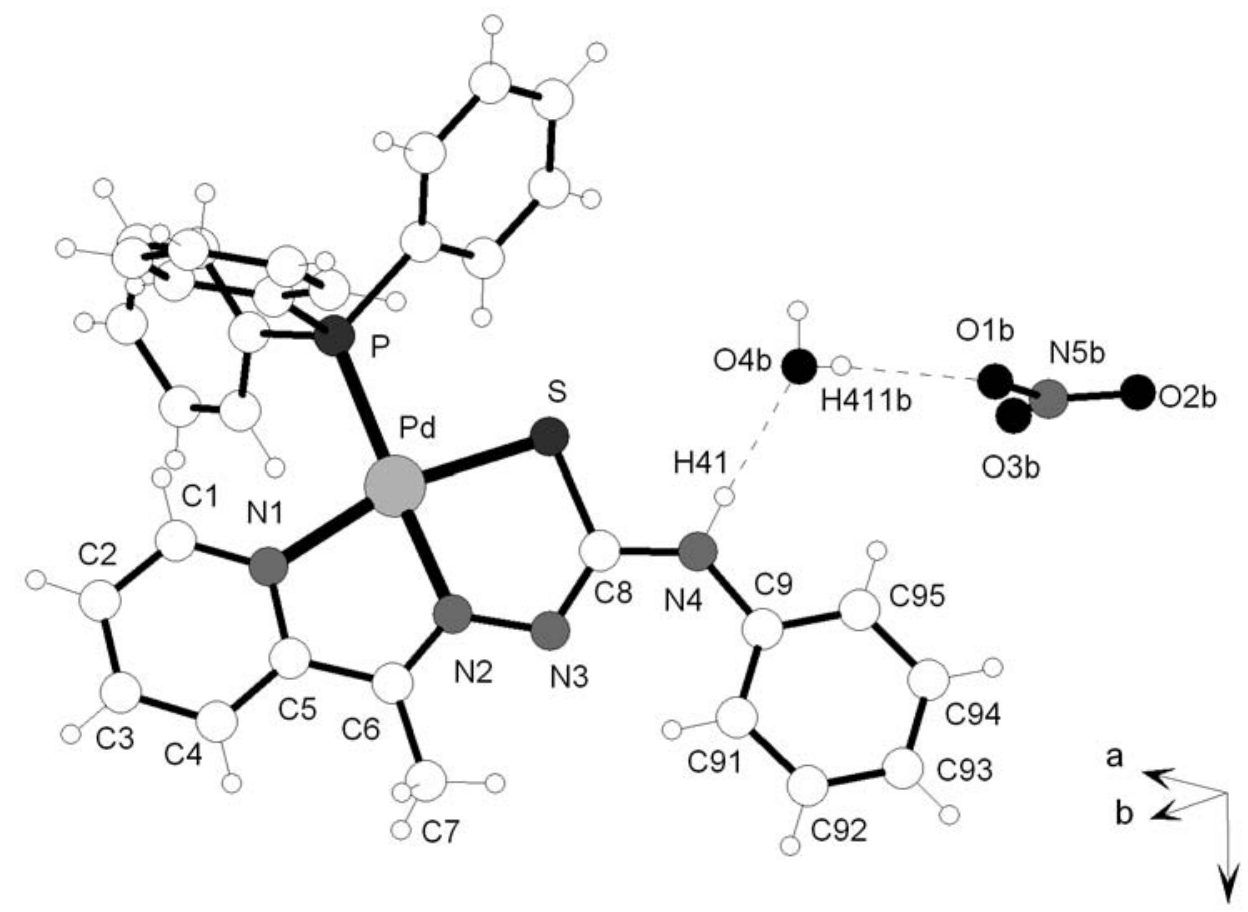

Figure S3. View of the crystal structure of $\left[\mathrm{Pd}(\mathrm{apptsc})\left(\mathrm{PPh}_{3}\right)\right]\left(\mathrm{NO}_{3}\right) \cdot \mathrm{H}_{2} \mathrm{O}(\mathbf{3})$ toward the direction [010], showing the hydrogen bonds as dashed lines. 